\title{
Silicon Amendment Reduces Soil Cd Availability and Cd Uptake of Two Pennisetum Species
}

\author{
Qiyu Dong ${ }^{1,2}$, Jianbo Fang ${ }^{3}$, Fei Huang ${ }^{1,2}$ and Kunzheng Cai ${ }^{1,2, *}$ \\ 1 Department of Ecology, College of Natural Resources and Environment, South China Agricultural \\ University, Guangzhou 510642, China; holmesball@163.com (Q.D.); feihuang@scau.edu.cn (F.H.) \\ 2 Key Laboratory of Tropical Agro-Environment, Ministry of Agriculture, South China Agricultural University, \\ Guangzhou 510642, China \\ 3 College of Forestry and Landscape Architecture, South China Agricultural University, Guangzhou 510642, \\ China; Jianbo2223@163.com \\ * Correspondence: kzcai@scau.edu.cn; Tel./Fax: +86-20-85280787
}

Received: 3 April 2019; Accepted: 6 May 2019; Published: 9 May 2019

\begin{abstract}
Silicon (Si) plays important roles in alleviating heavy metal stress, but the migrating effects and mechanisms, especially for Pennisetum, are not well studied. In this study, Pennisetum glaucum and Pennisetum glaucum $\times$ P. purpureum were used to explore the impacts of Si application on alleviating cadmium $(\mathrm{Cd})$ toxicity and its possible mechanism. Treatments consist of four levels of $\mathrm{Cd}\left(0,10,50\right.$, and $\left.100 \mathrm{mg} \cdot \mathrm{kg}^{-1}\right)$ with or without $2.0 \mathrm{mM} \mathrm{Si}$ amendments. Under Cd stress, Si application significantly increased plant biomass and Si content, reduced Cd content, and decreased the enrichment factor in shoots and roots. Si treatment also increased soil $\mathrm{pH}$ and soil residual $\mathrm{Cd}$, while reducing available/oxidizable/reducible Cd content in soil at 50 and $100 \mathrm{mg} \cdot \mathrm{kg}^{-1} \mathrm{Cd}$ levels, thereby leading to a reduction of the soil's available $\mathrm{Cd}$. These findings indicate that Si application is effective in alleviating $\mathrm{Cd}$ phytotoxicity of Pennisetum, mainly through reducing plant $\mathrm{Cd}$ uptake and increasing soil $\mathrm{pH}$ and $\mathrm{Cd}$ immobilization, thereby reducing $\mathrm{Cd}$ bioavailability.
\end{abstract}

Keywords: toxic metal elements; soil; cadmium; silicon; Pennisetum

\section{Introduction}

Cadmium (Cd), one of the most common toxic elements, is mainly discharged from industrial activities, such as mining, refining, plastic manufacturing, and electroplating [1]. Due to its high mobility and assimilability, $\mathrm{Cd}$ can easily get into plants through root uptake and being translocated to shoots in an ionic form in xylem and phloem through transporters and transpiration [2-5], causing a series of toxic effects on plants, including leaf chlorosis, growth inhibition, mineral nutrient disorders, accumulation of reactive oxygen species, protein denaturation, and even plant death [6,7]. Moreover, Cd can enter human organs via the food chain, consequently posing severe risks to human health, such as kidney, bone, and pulmonary damage [6-11]. Thus, developing reliable approaches to prevent heavy metal accumulation in plants is vital for reducing the potential risk in edible parts of crops.

Silicon (Si), one of the most abundant elements in the earth's crust, is second only to oxygen and accounts for $29.50 \%$ of the soil constituents $[1,12]$. Si has not been included as an essential element in higher plants [13], but many studies have shown that Si can be actively absorbed, translocated, and accumulated in massive amounts in many plants [14], and plays an important role in alleviating plant biotic and abiotic stresses $[15,16]$. It has been well documented that silicon enhances the tolerance of plants to toxic metal elements, including cadmium (Cd) [17], zinc (Zn) [18], manganese (Mn) [19], aluminum (Al) [20], chromium (Cr) [1], lead $(\mathrm{Pb})$ [21], and copper $(\mathrm{Cu})$ [22]. From previous research on crops, Si can alleviate the toxic effects of toxic metal elements on plants through external mechanisms and 
internal mechanisms. The external mechanisms include influencing $\mathrm{pH}$ and reducing the availability of toxic metal elements in soil, while internal mechanisms include influencing plant uptake, binding toxic metal elements in the cell walls, blocking the transport of toxic metal elements from roots to shoots, strengthening the defense system, and regulating protein and gene expression [23-28]. Farooq et al. [29] found that $\mathrm{Si}$ addition markedly enhanced cotton growth, gas-exchange parameters, and antioxidant enzyme activity in leaves, while decreasing $\mathrm{Cd}$ absorption, along with $\mathrm{H}_{2} \mathrm{O}_{2}$ and MDA content. Howladar et al. [30] found that silicon in different application methods increased polyamine contents and their gene expression. Vaculík et al. [31] showed that Si influenced the development of Casparian bands and suberin lamellae and vascular tissues in roots, leading to a decrease of $\mathrm{Cd}$ in symplasm in maize shoots. In the in situ analysis of cellular fluxes of the $\mathrm{Cd}^{2+}$ in suspension cells and root cells of rice exposed to $\mathrm{Cd}^{2+}$, Ma et al. [32] and Liu et al. [33] suggested that $\mathrm{Cd}$ ion uptake in rice could be suppressed by $\mathrm{Si}$ co-deposition of $\mathrm{Si}$ and $\mathrm{Cd}$ in the cell walls via a [Si-hemicellulose] $\mathrm{Cd}$ co-complexation; furthermore, $\mathrm{Cd}$ uptake in rice can be suppressed by $\mathrm{Si}$. Molecular evidence showed that Si reduced Cd uptake of (1) wheat, by down-regulating LCT1 and HMA2 proteins and up-regulating PCS1 and IRT1 proteins [34], and (2) rice, by down-regulating the transporter genes, OsNramp5 and OsHMA2 [35].

Pennisetum is annual and perennial high-quality forage of Gramineae, which is widely cultivated in tropical and subtropical regions. It has large biomass, luxuriant foliage, extended branches, a well-developed root system, fast growth, and strong stress resistance [36]. Pennisetum is rich in nutrition and can be used as green fodder and as silage material for herbivorous poultry and herbivorous fish. It has the functions of soil and water conservation, wind and sand fixation, energy supply, and it can also be used as an ornamental plant. Furthermore, Pennisetum is highly tolerant to heavy metals, it has a strong accumulation capacity, and is used as an environmental remediation grass species [37]. At present, the mitigating effect of Si on toxic metal elements in plants mostly focuses on crops, but is not reported in grass so far. Therefore, this study was conducted to: (1) Investigate the impacts of exogenous Si application on plant growth, Cd uptake in Pennisetum plants, and soil Cd availability at different doses of $\mathrm{Cd}$ contamination; and (2) identify the possible mechanisms involved in Si-mediated Cd detoxification.

\section{Materials and Methods}

\subsection{Plant Materials and Growth Conditions}

Pennisetum glaucum and Pennisetum glaucum $\times$ Pennisetum purpureum were used as experimental materials. P. glaucum is an annual grass of Gramineae found in Africa. It has the characteristics of an erect-stem, strong-root system with corrugated-edge leaves. P. glaucum $\times$ P. purpureum is a hybrid of P. glaucum and P. purpureum, and it is a perennial grass of Gramineae. It has thick stems, better tillering ability, strong fibrous roots, and long broad leaves with bristles on the edges and thin hair on the surface. The Pennisetum seeds were provided by Henan Shijitianyuan Ecological Technology Limited Company, China.

\subsection{Experimental Treatments}

The experiment was performed in the greenhouse of the South China Agricultural University Ecological Farm $\left(23.21^{\circ} \mathrm{N}, 113.42^{\circ} \mathrm{E}\right)$. Full and lustrous Pennisetum seeds were surface sterilized in $3 \%$ $\mathrm{H}_{2} \mathrm{O}_{2}$ for $20 \mathrm{~min}$, and then rinsed with deionized water 3 times [1]. The seeds were germinated by immersion in deionized water at $28^{\circ} \mathrm{C}$ in the dark for $24 \mathrm{~h}$. After germination, six uniform seedlings were selected and transferred to plastic pots $(22 \mathrm{~cm} \times 26 \mathrm{~cm} \times 17 \mathrm{~cm})$, containing $2.5 \mathrm{~kg}$ soil. The soil was artificial soil mixed with peat soil and sand. The properties of the soil are shown in Table 1. To ensure the normal growth of Pennisetum during the experiment, urea $\left(1.70 \mathrm{~g} \cdot \mathrm{pot}^{-1}\right)$ and potassium dihydrogen phosphate $\left(1.16 \mathrm{~g} \cdot \mathrm{pot}^{-1}\right)$ were employed as base fertilizers in each pot before transplanting, and the fertilizer was supplemented according to the development during the growth period. 
Table 1. The basic soil chemical properties.

\begin{tabular}{cccccccc}
\hline $\mathbf{p H}$ & $\begin{array}{c}\text { Organic Matter } \\
\left(\mathbf{g} \cdot \mathbf{k g}^{-\mathbf{1}}\right)\end{array}$ & $\begin{array}{c}\text { Total N } \\
\left(\mathbf{g} \cdot \mathbf{k g}^{-\mathbf{1}}\right)\end{array}$ & $\begin{array}{c}\text { Total P } \\
\left(\mathbf{g} \cdot \mathbf{k g}^{-\mathbf{1}}\right)\end{array}$ & $\begin{array}{c}\text { Total K } \\
\left(\mathbf{g} \cdot \mathbf{k g}^{-\mathbf{1}}\right)\end{array}$ & $\begin{array}{c}\text { Available N } \\
\left(\mathbf{m g} \cdot \mathbf{k g}^{-\mathbf{1}}\right)\end{array}$ & $\begin{array}{c}\text { Available P } \\
\left(\mathbf{m g} \cdot \mathbf{k g}^{-\mathbf{1}}\right)\end{array}$ & $\begin{array}{c}\text { Available K } \\
\left(\mathbf{m g} \cdot \mathbf{k g}^{-\mathbf{1}}\right)\end{array}$ \\
\hline 5.58 & 111.32 & 1.50 & 0.21 & 11.66 & 155.34 & 57.30 & 174.10 \\
\hline
\end{tabular}

Eight treatments with three replicates were involved in this experiment: Four levels of Cd supply $\left(0,10,50\right.$, and $\left.100 \mathrm{mg} \cdot \mathrm{kg}^{-1}\right)$ with or without $2.0 \mathrm{mM}$ Si application for P. glaucum and P. glaucum $\times$ P. purpureum. $\mathrm{CdCl}_{2}$ and $\mathrm{K}_{2} \mathrm{SiO}_{3}$ were mixed into the soil, and soil moisture was kept at $60-70 \%$ of the field water holding capacity for 7 days. After two months, plant and soil samples were collected for the determination of various parameters.

\subsection{Plant Samples Analysis}

Harvested plant samples in each treatment were separated into roots and shoots, dried at $110{ }^{\circ} \mathrm{C}$ for $30 \mathrm{~min}$, and then dried at $65^{\circ} \mathrm{C}$ until the materials reached their constant weights. The biomass of shoots and roots was weighed. Si concentration in roots and shoots was measured according to the modified autoclave-induced digestion method by Elliott et al. [38]. In brief, dried plant samples were dissolved with $3 \mathrm{~mL}$ of $50 \% \mathrm{NaOH}$ solution at $121{ }^{\circ} \mathrm{C}$ for $2 \mathrm{~h}$. Afterward, $30 \mathrm{~mL} 20 \%$ acetic acid, $10 \mathrm{~mL}$ ammonium molybdate (54 g. $\left.\mathrm{L}^{-1}, \mathrm{pH} 7.0\right), 5 \mathrm{~mL} \mathrm{20 \%}$ tartaric acid, and $1 \mathrm{~mL}$ reductant were added to $1 \mathrm{~mL}$ of the samples. After $30 \mathrm{~min}$, Si concentration of the samples was measured at $650 \mathrm{~nm}$ on a TU-1901 UV-Vis spectrophotometer (TU-1901, Beijing Purkinje General Instrument Co., Ltd., Beijing, China). To determine $\mathrm{Cd}$ concentration in plants, the dried plant samples (roots and shoots) were ground into powder and digested with a mixture solution $\left(9 \mathrm{~mL} \mathrm{HNO}_{3}\right.$ and $\left.1 \mathrm{~mL} \mathrm{H}_{2} \mathrm{O}_{2}\right)$, using a microwave digestion instrument (Mars 6, CEM Corporation, USA). The Cd levels in the plant samples were determined using atomic absorbance spectrometry (ZEEnit ${ }^{\circledR} 700 \mathrm{P}$, Analytik Jena AG, Jena, Germany). The enrichment factor $(\mathrm{EF})=\mathrm{Cd}$ concentration in roots (shoots)/Cd concentration in soil, and the translocation factor $(\mathrm{TF})=\mathrm{Cd}$ concentration in shoots/ $\mathrm{Cd}$ concentration in roots.

\subsection{Soil Samples Analysis}

To determine soil $\mathrm{pH}, 10 \mathrm{~g}$ of the air-dried soil samples were weighed and mixed with distilled water. Soil pH was measured with a pH meter (STARTER2100, Ohaus, Parsippany, NJ, USA) [39]. To determine $\mathrm{Cd}$ concentration in soil, $0.15 \mathrm{~g}$ of dried soil samples were digested with $8 \mathrm{~mL} \mathrm{HNO}_{3}, 2$ $\mathrm{mL} \mathrm{HF}$, and $1 \mathrm{~mL} \mathrm{H}_{2} \mathrm{O}_{2}$, using a microwave digestion instrument (Mars 6, CEM Corporation, Matthews, NC, USA) [40]. To determine the $\mathrm{Cd}$ fractions in soil, $\mathrm{Cd}$ concentration in various soil fractions was extracted according to the modified BCR method [41]. In brief, $1.0 \mathrm{~g}$ dried soil samples were weighed. The exchangeable $\mathrm{Cd}$ form was extracted by $40 \mathrm{~mL} 0.11 \mathrm{~mol} \cdot \mathrm{L}^{-1} \mathrm{HAc}$ on oscillator at room temperature for $16 \mathrm{~h}\left(250 \mathrm{r} \cdot \mathrm{min}^{-1}\right)$, the reducible $\mathrm{Cd}$ fraction was extracted by $0.5 \mathrm{~mol} \cdot \mathrm{L}^{-1} \mathrm{NH}_{2} \mathrm{OH} \cdot \mathrm{HCl}$ on oscillator under the same conditions, and the oxidizable $\mathrm{Cd}$ fraction was digested with $30 \% \mathrm{H}_{2} \mathrm{O}_{2}$ in $85{ }^{\circ} \mathrm{C}$ water. Then, $50 \mathrm{~mL}$ of $1 \mathrm{~mol} \cdot \mathrm{L}^{-1} \mathrm{NH}_{4} \mathrm{OAc}$ was added after cooling and the residual $\mathrm{Cd}$ fraction was digested with $10 \mathrm{~mL} \mathrm{HNO}_{3}, 10 \mathrm{~mL} \mathrm{HF}$, and $3 \mathrm{~mL} \mathrm{HClO}_{4}$ in a hot plate, dissolved with distilled water and transferred to a $25 \mathrm{~mL}$ volumetric flask. The $\mathrm{Cd}$ content and fractions in soil were determined using atomic absorbance spectrometry (ZEEnit ${ }^{\circledR} 700 P$, Analytik Jena, AG, Jena, Germany).

\subsection{Statistical Analysis}

All data were expressed as the mean \pm standard deviation of the three replicates. Statistical analysis was performed using SPSS 18.0 (IBM, New York, NY, USA), and data differences among treatments with the same material were analyzed by one-way ANOVA and the Duncan test $(p<0.05)$. 


\section{Results}

\subsection{Effects of Si on Plant Biomass}

Si had beneficial effects in enhancing plant resistance against $\mathrm{Cd}$ stress for both Pennisetum. As Cd application level increased, the biomass in roots and shoots decreased gradually. For P. glaucum $\times$ P. purpureum (Figure 1a,c), Si addition significantly increased shoot biomass by $18.62-148.98 \%$ and root biomass by 25.94-164.68\% under different Cd levels. Similarly, Si increased the shoot biomass by $12.65-101.46 \%$ and root biomass by $49.97-143.67 \%$ for P. glaucum, regardless of Cd stress (Figure 1b,d).

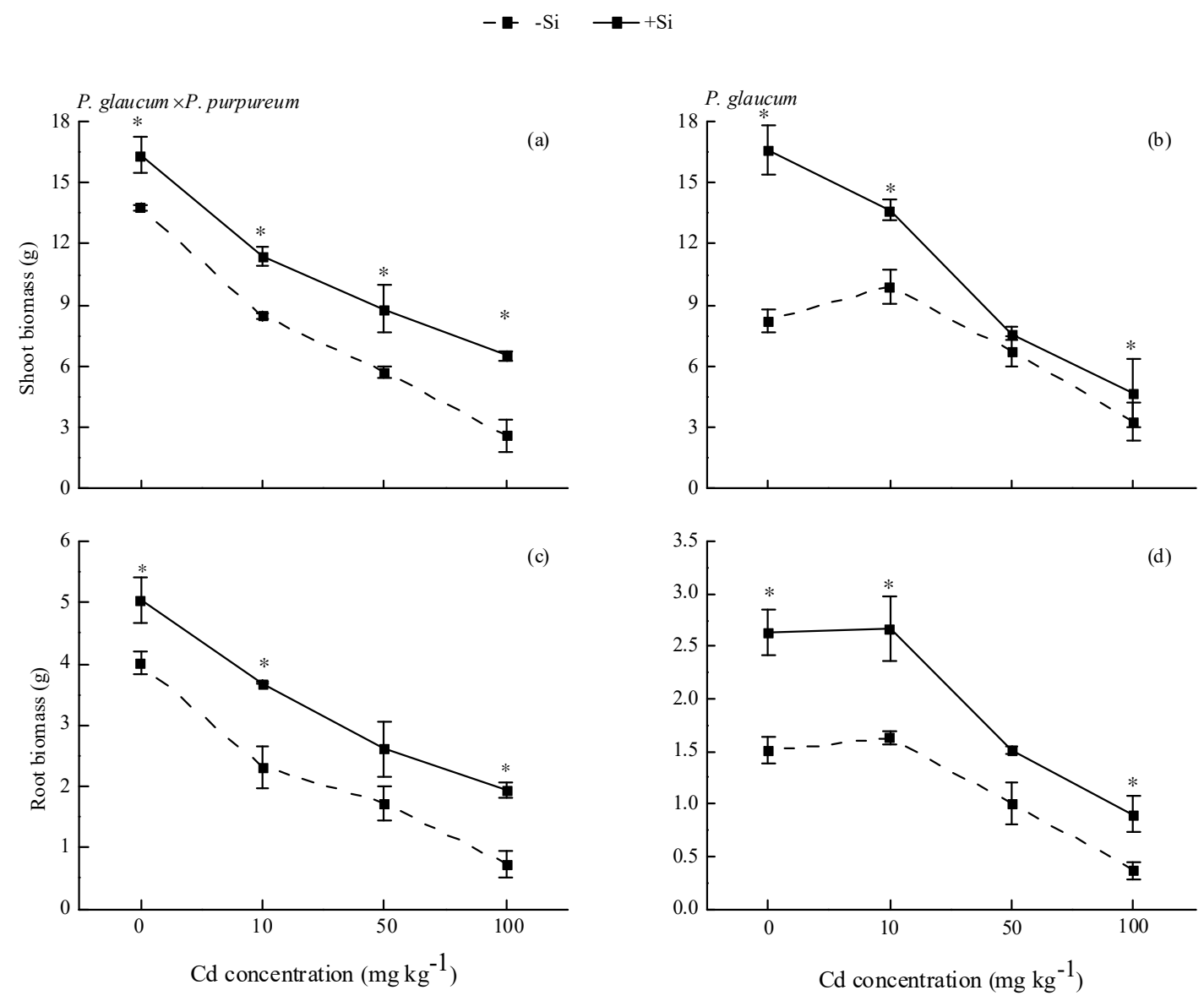

Figure 1. Effects of $\mathrm{Si}$ on the biomass of Pennisetum under Cd stress. (a,c) shoot and root biomass of P. glaucum $\times$ P. purpureum; $(\mathbf{b}, \mathbf{d})$ shoot and root biomass of $P$. glaucum. Values are mean \pm SE $(n=3)$. * indicates significant difference between different treatments of the same variety, according to one-way ANOVA followed by the Duncan test $(p<0.05)$.

\subsection{Effect of Si on Cd/Si Accumulation in Plants and the Enrichment Factor (EF)}

A single Cd treatment did not influence plant Si concentration. Si application significantly increased Si uptake and reduced Cd concentration in roots and shoots for both varieties (Table 2). For P. glaucum $\times$ P. purpureum, Si addition increased Si concentration in shoots by $13.70-46.76 \%$ and in roots by $42.34-56.17 \%$. Similarly, Si significantly increased Si concentration in shoots by $19.61-20.61 \%$ and in roots by $29.24-52.66 \%$ for P. glaucum, except for shoot Si concentration under the 0 and $100 \mathrm{mg} \cdot \mathrm{kg}^{-1} \mathrm{Cd}$ stress conditions (Table 2). 
Table 2. Cd enrichment of Pennisetum with/without Si.

\begin{tabular}{|c|c|c|c|c|c|c|c|c|c|c|c|}
\hline \multirow[t]{2}{*}{ Variety } & \multirow{2}{*}{$\begin{array}{c}\mathrm{Cd} \\
\text { Treatments }\end{array}$} & \multirow{2}{*}{$\begin{array}{c}\mathrm{Si} \\
\text { Treatments }\end{array}$} & \multicolumn{2}{|c|}{$\begin{array}{c}\text { Si Concentration } \\
\mathrm{mg} \cdot \mathrm{kg}^{-1}\end{array}$} & \multicolumn{2}{|c|}{$\begin{array}{c}\text { Cd Concentration } \\
\mathrm{mg} \cdot \mathrm{kg}^{-1}\end{array}$} & \multicolumn{2}{|c|}{$\begin{array}{c}\text { Cd Accumulation } \\
\text { mg.pot }^{-1}\end{array}$} & \multicolumn{2}{|c|}{$\begin{array}{l}\text { Enrichment Factor } \\
\text { (EF) }\end{array}$} & \multirow{2}{*}{$\begin{array}{l}\text { Translocation } \\
\text { Factor } \\
\text { (TF) }\end{array}$} \\
\hline & & & Shoots & Roots & Shoots & Roots & Shoots & Roots & Shoots & Roots & \\
\hline \multirow{4}{*}{$\begin{aligned} & \text { P. glaucum } \\
\times & \text { P. purpureum }\end{aligned}$} & 0 & $\begin{array}{l}-\mathrm{Si} \\
+\mathrm{Si}\end{array}$ & $\begin{array}{c}6.12 \pm 0.14 \mathrm{bcde} \\
6.38 \pm 0.20 \mathrm{abc}\end{array}$ & $\begin{array}{l}4.04 \pm 0.46 c \\
6.29 \pm 0.25 b\end{array}$ & & & & & & & \\
\hline & 10 & $\begin{array}{l}-\mathrm{Si} \\
+\mathrm{Si}\end{array}$ & $\begin{array}{c}5.53 \pm 0 \mathrm{e} \\
6.61 \pm 0.29 \mathrm{ab}\end{array}$ & $\begin{array}{c}4.7 \pm 0.05 c \\
7.34 \pm 0.36 a\end{array}$ & $\begin{array}{c}22.79 \pm 0.93 \mathrm{~d} \\
15.38 \pm 0.6 \mathrm{~d}\end{array}$ & $\begin{array}{c}15.78 \pm 0.72 \mathrm{~cd} \\
10.7 \pm 0.41 \mathrm{~d}\end{array}$ & $\begin{array}{c}0.19 \pm 0.01 \mathrm{ab} \\
0.18 \pm 0.01 \mathrm{~b}\end{array}$ & $\begin{array}{l}0.04 \pm 0 \mathrm{a} \\
0.04 \pm 0 \mathrm{a}\end{array}$ & $\begin{array}{l}1.31 \pm 0.11 \mathrm{a} \\
0.43 \pm 0.22 \mathrm{~b}\end{array}$ & $\begin{array}{l}0.90 \pm 0.04 \mathrm{a} \\
0.30 \pm 0.03 \mathrm{c}\end{array}$ & $\begin{array}{r}1.45 \pm 0.066 \mathrm{a} \\
1.44 \pm 0.08 \mathrm{a}\end{array}$ \\
\hline & 50 & $\begin{array}{l}-\mathrm{Si} \\
+\mathrm{Si}\end{array}$ & $\begin{array}{c}5.78 \pm 0.11 \mathrm{cde} \\
6.98 \pm 0.38 \mathrm{a}\end{array}$ & $\begin{array}{l}4.38 \pm 0.05 c \\
6.36 \pm 0.24 b\end{array}$ & $\begin{array}{l}44.95 \pm 1.21 b \\
34.44 \pm 1.08 \mathrm{c}\end{array}$ & $\begin{array}{c}34.47 \pm 2.39 \mathrm{~b} \\
19.81 \pm 1.48 \mathrm{~cd}\end{array}$ & $\begin{array}{c}0.26 \pm 0.02 \mathrm{ab} \\
0.31 \pm 0.05 \mathrm{a}\end{array}$ & $\begin{array}{l}0.06 \pm 0.01 \mathrm{a} \\
0.05 \pm 0.01 \mathrm{a}\end{array}$ & $\begin{array}{c}0.49 \pm 0.04 b \\
0.19 \pm 0.01 \mathrm{c}\end{array}$ & $\begin{array}{c}0.37 \pm 0.03 \mathrm{bc} \\
0.11 \pm 0.01 \mathrm{~d}\end{array}$ & $\begin{array}{l}1.31 \pm 0.06 \mathrm{a} \\
1.76 \pm 0.16 \mathrm{a}\end{array}$ \\
\hline & 100 & $\begin{array}{l}-\mathrm{Si} \\
+\mathrm{Si}\end{array}$ & $\begin{array}{c}5.68 \pm 0.09 \mathrm{de} \\
6.18 \pm 0.00 \mathrm{bcd}\end{array}$ & $\begin{array}{c}4.70 \pm 0.05 c \\
6.69 \pm 0.39 \mathrm{ab}\end{array}$ & $\begin{array}{c}80.62 \pm 3.95 a \\
36.88 \pm 5.29 b c\end{array}$ & $\begin{array}{l}110.32 \pm 7.29 \mathrm{a} \\
24.98 \pm 1.38 \mathrm{bc}\end{array}$ & $\begin{array}{l}0.21 \pm 0.07 \mathrm{ab} \\
0.24 \pm 0.03 \mathrm{ab}\end{array}$ & $\begin{array}{c}0.08 \pm 0.03 \mathrm{a} \\
0.05 \pm 0 \mathrm{a}\end{array}$ & $\begin{array}{c}0.32 \pm 0.05 b c \\
0.16 \pm 0.03 c\end{array}$ & $\begin{array}{l}0.43 \pm 0.07 \mathrm{~b} \\
0.11 \pm 0.02 \mathrm{~d}\end{array}$ & $\begin{array}{l}0.73 \pm 0.02 b \\
1.51 \pm 0.30 a\end{array}$ \\
\hline \multirow{4}{*}{ P. glaucum } & 0 & $\begin{array}{l}-\mathrm{Si} \\
+\mathrm{Si}\end{array}$ & $\begin{array}{l}5.9 \pm 0.15 \mathrm{de} \\
6.71 \pm 0.06 \mathrm{bc}\end{array}$ & $\begin{array}{c}4.53 \pm 0.34 \mathrm{f} \\
6.79 \pm 0.09 \mathrm{~cd}\end{array}$ & & & & & & & \\
\hline & 10 & $\begin{array}{l}-\mathrm{Si} \\
+\mathrm{Si}\end{array}$ & $\begin{array}{c}5.53 \pm 0.00 \mathrm{ef} \\
8.11 \pm 0.49 \mathrm{a}\end{array}$ & $\begin{array}{c}6.19 \pm 0.31 \mathrm{~d} \\
8.00 \pm 0.15 \mathrm{ab}\end{array}$ & $\begin{array}{l}16.05 \pm 0.11 \mathrm{~d} \\
11.29 \pm 0.98 \mathrm{~d}\end{array}$ & $\begin{array}{r}9.87 \pm 0.78 \mathrm{~d} \\
13.68 \pm 2.77 \mathrm{~d}\end{array}$ & $\begin{array}{l}0.16 \pm 0.01 a \\
0.15 \pm 0.01 a\end{array}$ & $\begin{array}{c}0.02 \pm 0 \mathrm{c} \\
0.04 \pm 0.01 \mathrm{bc}\end{array}$ & $\begin{array}{l}0.70 \pm 0.01 \mathrm{a} \\
0.32 \pm 0.04 \mathrm{~b}\end{array}$ & $\begin{array}{l}0.43 \pm 0.03 \mathrm{ab} \\
0.39 \pm 0.09 \mathrm{ab}\end{array}$ & $\begin{array}{l}1.65 \pm 0.13 a \\
0.88 \pm 0.14 b\end{array}$ \\
\hline & 50 & $\begin{array}{l}-\mathrm{Si} \\
+\mathrm{Si}\end{array}$ & $\begin{array}{l}6.6 \pm 0.30 \mathrm{bcd} \\
7.29 \pm 0.10 \mathrm{~b}\end{array}$ & $\begin{array}{c}5.91 \pm 0.61 \mathrm{de} \\
8.67 \pm 0.20 \mathrm{a}\end{array}$ & $\begin{array}{l}34.88 \pm 1.96 \mathrm{~b} \\
27.37 \pm 0.70 \mathrm{c}\end{array}$ & $\begin{array}{c}68.88 \pm 4.6 \mathrm{~b} \\
32.57 \pm 2.74 \mathrm{c}\end{array}$ & $\begin{array}{c}0.23 \pm 0.02 \mathrm{a} \\
0.21 \pm 0 \mathrm{a}\end{array}$ & $\begin{array}{c}0.07 \pm 0.02 \mathrm{a} \\
0.05 \pm 0 \mathrm{ab}\end{array}$ & $\begin{array}{l}0.17 \pm 0.01 \mathrm{c} \\
0.11 \pm 0.00 \mathrm{c}\end{array}$ & $\begin{array}{c}0.33 \pm 0.01 b c \\
0.13 \pm 0.01 \mathrm{c}\end{array}$ & $\begin{array}{l}0.51 \pm 0.03 c \\
0.85 \pm 0.08 b\end{array}$ \\
\hline & 100 & $\begin{array}{l}-\mathrm{Si} \\
+\mathrm{Si}\end{array}$ & $\begin{array}{c}.98 \pm 0.19 \mathrm{f} \\
6.55 \pm 0.05 \mathrm{~cd}\end{array}$ & $\begin{array}{l}4.88 \pm 0.28 \mathrm{ef} \\
7.45 \pm 0.58 \mathrm{bc}\end{array}$ & $\begin{array}{l}61.98 \pm 2.52 a \\
39.23 \pm 3.75 b\end{array}$ & $\begin{array}{c}117.54 \pm 6.15 \mathrm{a} \\
66.03 \pm 5.77 \mathrm{~b}\end{array}$ & $\begin{array}{l}0.20 \pm 0.05 a \\
0.18 \pm 0.06 a\end{array}$ & $\begin{array}{l}0.04 \pm 0.01 \mathrm{ab} \\
0.06 \pm 0.01 \mathrm{ab}\end{array}$ & $\begin{array}{l}0.33 \pm 0.01 b \\
0.11 \pm 0.00 \mathrm{c}\end{array}$ & $\begin{array}{c}0.62 \pm 0.16 \mathrm{a} \\
0.18 \pm 0.02 \mathrm{bc}\end{array}$ & $\begin{array}{l}0.53 \pm 0.03 \mathrm{c} \\
0.6 \pm 0.06 \mathrm{bc}\end{array}$ \\
\hline
\end{tabular}

Values are mean $\pm \mathrm{SE}(n=3)$. Values followed by the different letters indicate significant differences between different treatments of the same variety, according to one-way ANOVA

followed by the Duncan test $(p<0.05)$. 
With the increase of the Cd treatment level, Cd concentration in roots and shoots increased significantly for both Pennisetum (Table 2). At 50 and $100 \mathrm{mg} \cdot \mathrm{kg}^{-1} \mathrm{Cd}$ levels, Cd concentration in roots of $P$. glaucum $\times$ P. purpureum were higher than those in the shoots. Similar results were obtained with $P$. glaucum under $100 \mathrm{mg} \cdot \mathrm{kg}^{-1} \mathrm{Cd}$ level. Si addition significantly reduced Cd concentration in the roots and shoots of the two varieties, except under the $10 \mathrm{mg} \cdot \mathrm{kg}^{-1} \mathrm{Cd}$ stress condition (Table 2). For P. glaucum $\times$ P. purpureum, Si application reduced Cd concentration by $23.38 \%$ and $54.26 \%$ in shoots and by $42.53 \%$ and $77.36 \%$ in roots under 50 and $100 \mathrm{mg} \cdot \mathrm{kg}^{-1} \mathrm{Cd}$ treatments, respectively. The corresponding reductions in P. glaucum were $21.53 \%$ and $36.71 \%$ in shoots and $52.72 \%$ and $43.82 \%$ in roots, respectively (Table 2). However, Si did not influence $\mathrm{Cd}$ accumulation in shoots and roots for both varieties under different $\mathrm{Cd}$ treatment levels.

The EF, which represents the degree of toxic metal element enrichment in plants, is the ratio of $\mathrm{Cd}$ content in each plant organ to the $\mathrm{Cd}$ content in soil. The TF, which represents the ability of toxic metal elements to transfer from root to shoot, is the ratio of the $\mathrm{Cd}$ content of the above-ground organs to the root. As shown in Table 2, for P. glaucum $\times$ P. purpureum, Si addition significantly decreased the EF in shoots by $50.00-67.18 \%$ and in roots by $66.67-74.42 \%$, respectively, except for the EF in shoots under the $100 \mathrm{mg} \cdot \mathrm{kg}^{-1} \mathrm{Cd}$ treatment. In general, Si did not influence TF, except under $100 \mathrm{mg} \cdot \mathrm{kg}^{-1} \mathrm{Cd}$ treatment, where TF was $106.85 \%$ higher in Si-treated plants than in non-Si-treated ones. Similarly, for P. glaucum, EF values were decreased by $54.29 \%$ and $66.67 \%$ in shoots after silicon addition under 10 and $100 \mathrm{mg} \cdot \mathrm{kg}^{-1} \mathrm{Cd}$ treatments, respectively, and by $70.97 \%$ in roots under the $100 \mathrm{mg} \cdot \mathrm{kg}^{-1} \mathrm{Cd}$. However, the TF decreased by $46.67 \%$ under $10 \mathrm{mg} \cdot \mathrm{kg}^{-1} \mathrm{Cd}$ and increased by $66.67 \%$ under $50 \mathrm{mg} \cdot \mathrm{kg}^{-1}$ $\mathrm{Cd}$ after Si addition.

\subsection{Effects of Si Application on Soil $p H$}

Si addition significantly increased soil $\mathrm{pH}$ (Figure 2). In P. glaucum $\times$ P. purpureum, the $\mathrm{pH}$ values of Si-treated soils were $0.07,0.30$, and 0.25 units higher than those of single Cd treatment $(0,10$, and $100 \mathrm{mg} \cdot \mathrm{kg}^{-1} \mathrm{Cd}$ stress), respectively; similarly, in P. glaucum, the $\mathrm{pH}$ values of Si-treated soils were 0.24 , $0.39,0.02$, and 0.09 units higher than those of single $\mathrm{Cd}$ treatment $\left(0,10,50\right.$, and $100 \mathrm{mg} \cdot \mathrm{kg}^{-1} \mathrm{Cd}$ stress).

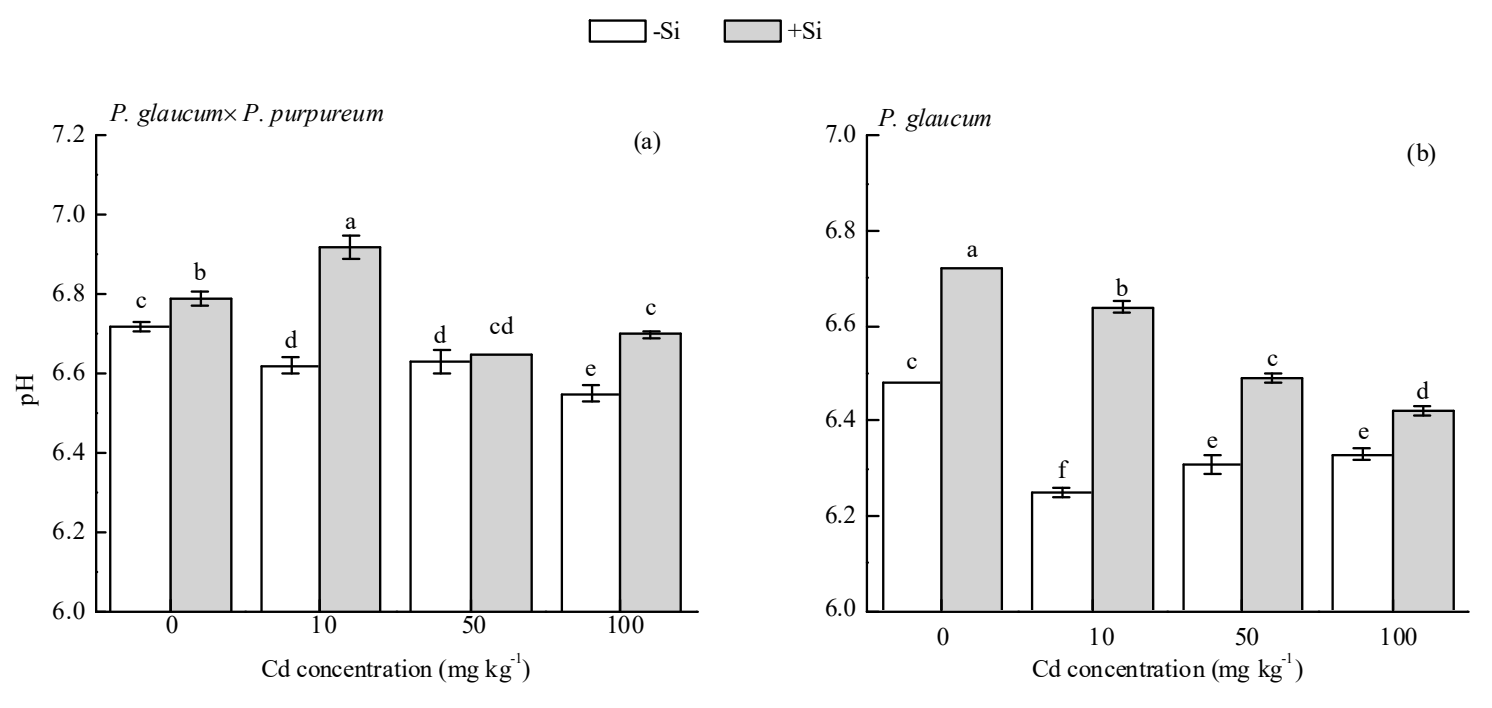

Figure 2. Effect of Si on soil pH of (a) P. glaucum $\times$ P. purpureum and (b) P. glaucum. Values are mean \pm $\mathrm{SE}(n=3)$. Values followed by the different letters indicate significant differences between different treatments of the same variety, according to one-way ANOVA and Duncan test $(p<0.05)$.

\subsection{Effect of Si on Total Cd and Cd Fractions in Soil}

As shown in Figure 3, Si addition significantly increased total soil Cd concentration by $100.34 \%$ under the $50 \mathrm{mg} \cdot \mathrm{kg}^{-1} \mathrm{Cd}$ level for P. glaucum $\times$ P. purpureum (Figure $3 \mathrm{a}$ ) and by $66.97 \%$ under the $100 \mathrm{mg} \cdot \mathrm{kg}^{-1} \mathrm{Cd}$ level for P. glaucum (Figure 3b). 


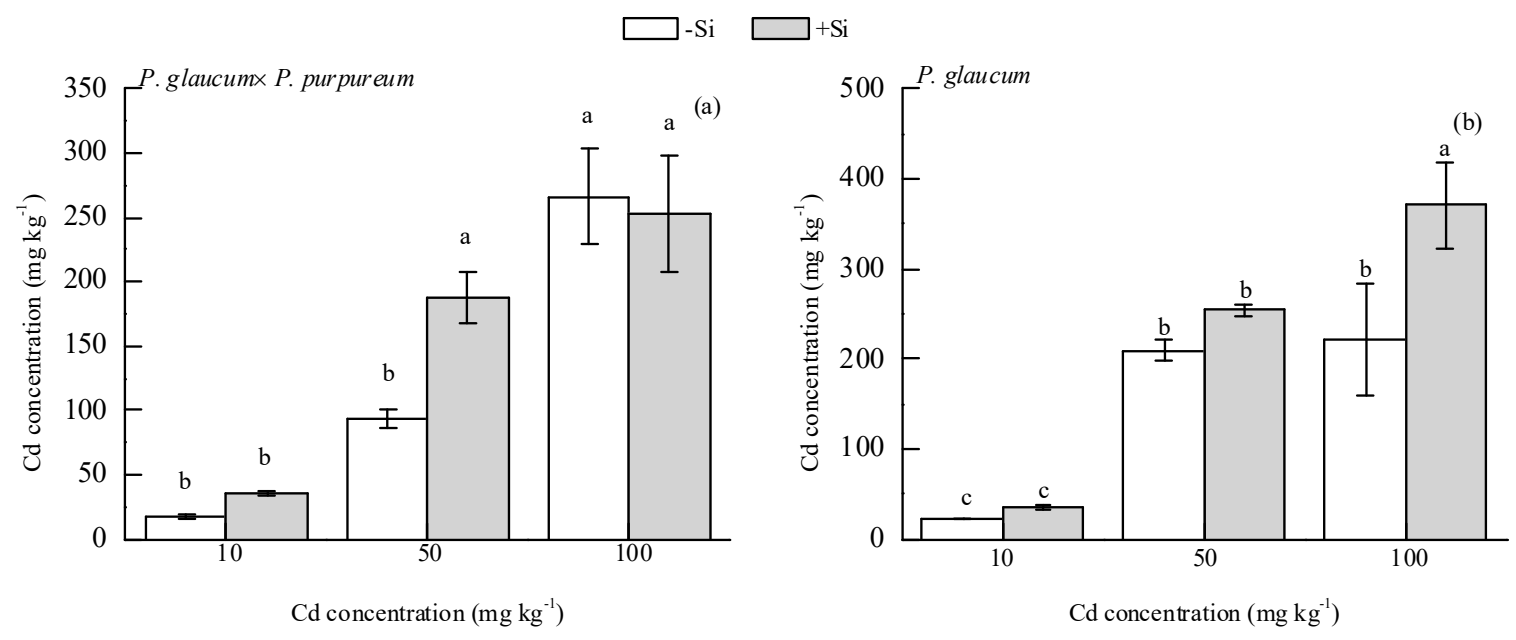

Figure 3. Effect of Si on soil total Cd concentration of (a) P. glaucum $\times$ P. purpureum and (b) P. glaucum. Values are mean \pm SE $(n=3)$. Values followed by the different letters indicate significant differences between different treatments of the same variety, according to one-way ANOVA followed by the Duncan test $(p<0.05)$.

Four fractions of $\mathrm{Cd}$ are tested in soil: Exchangeable, oxidizable, reducible, and residual fractions [42]. Si treatment had significant effects on the concentration of different fractions of soil $\mathrm{Cd}$, but this effect varied among different $\mathrm{Cd}$ levels and Pennisetum varieties. Si did not influence soil $\mathrm{Cd}$ fractions under the $10 \mathrm{mg} \cdot \mathrm{kg}^{-1} \mathrm{Cd}$ level for both varieties. For P. glaucum $\times$ P. purpureum (Figure $4 \mathrm{a}, \mathrm{c}, \mathrm{e}, \mathrm{g}$ ), under the $50 \mathrm{mg} \cdot \mathrm{kg}^{-1} \mathrm{Cd}$ level, Si decreased soil exchangeable $\mathrm{Cd}$ by $65.90 \%$, and increased reducible and oxidizable Cd by $145.22 \%$ and $120.26 \%$, respectively. Under the $100 \mathrm{mg} \cdot \mathrm{kg}^{-1} \mathrm{Cd}$ level, Si decreased the reducible and oxidizable Cd by $60.79 \%$ and $70.43 \%$, respectively, and increased the residual Cd by $136.07 \%$. Similarly, Si had significant effects on soil exchangeable and residual Cd in P. glaucum (Figure $4 \mathrm{~b}, \mathrm{~d}, \mathrm{f}, \mathrm{h}$ ). For example, Si decreased exchangeable Cd by $39.28 \%$ and $32.96 \%$ and increased residual Cd by $31.38 \%$ and $30.97 \%$ under the 50 and $100 \mathrm{mg} \cdot \mathrm{kg}^{-1} \mathrm{Cd}$ levels, respectively.

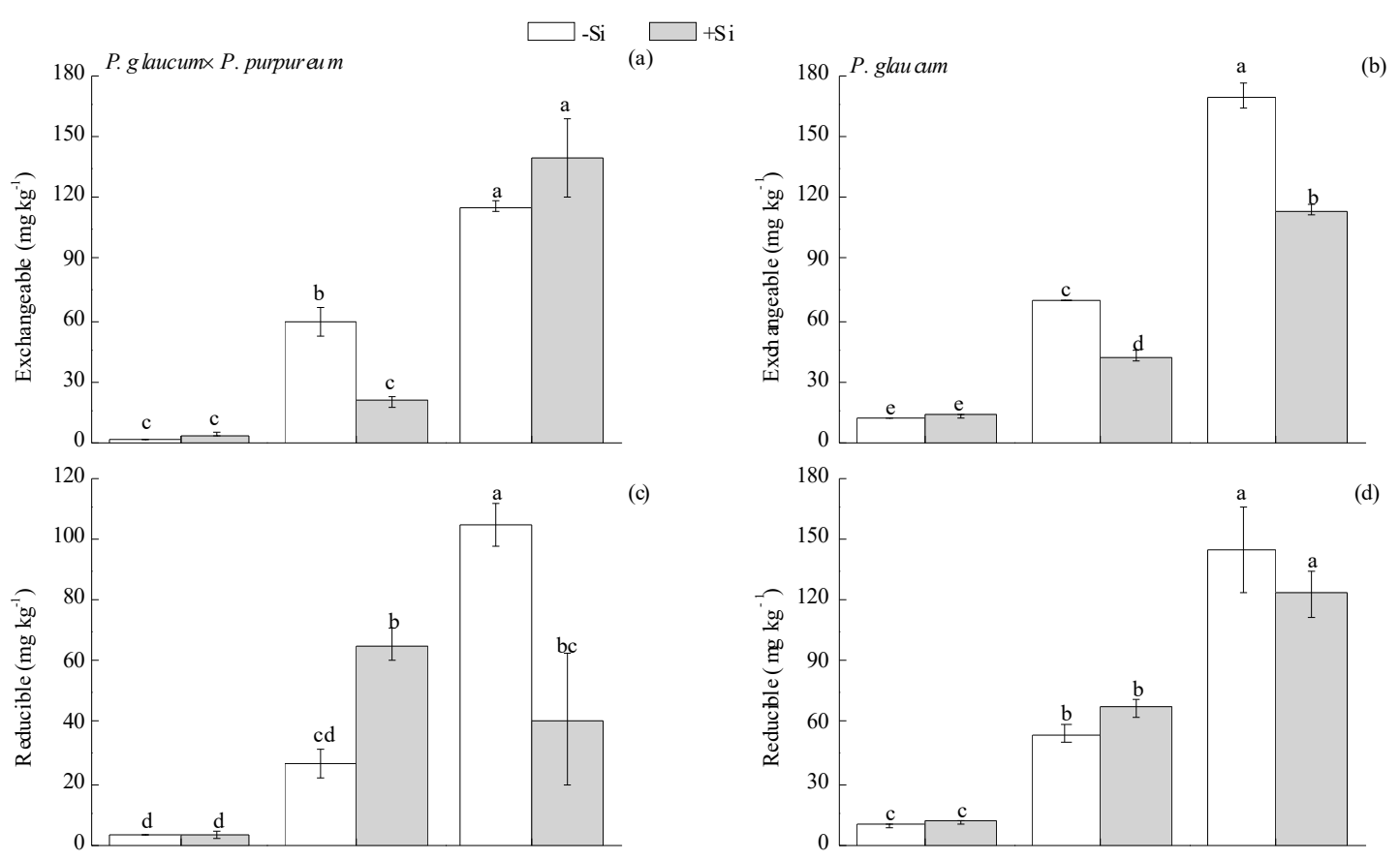

Figure 4. Cont. 


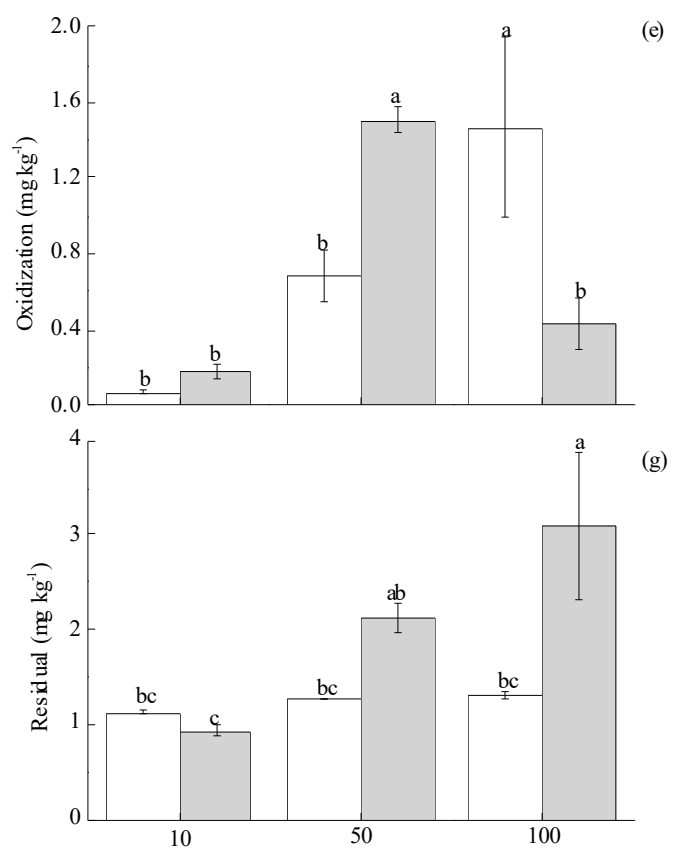

Cd concentration $\left(\mathrm{mg} \mathrm{kg}^{-1}\right)$

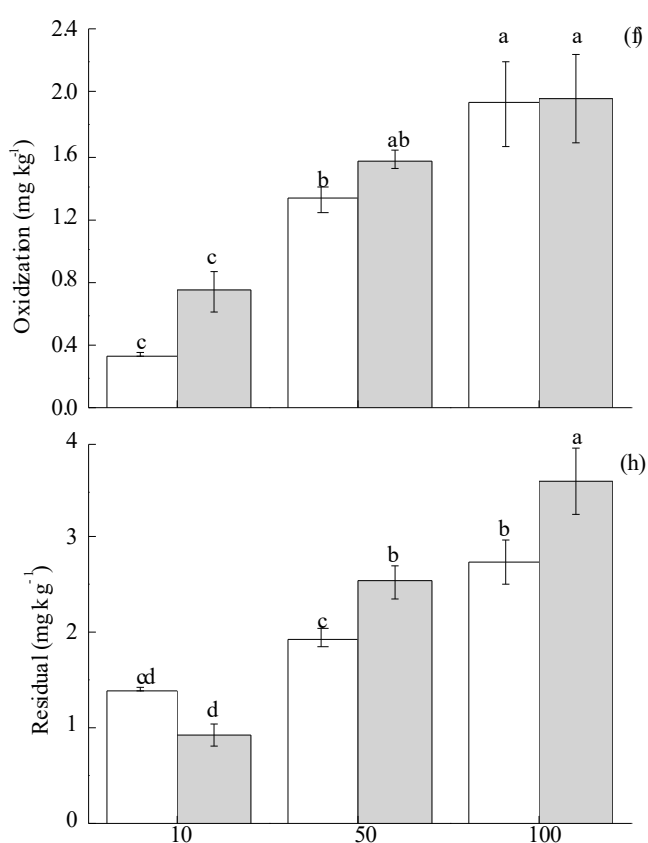

Cd concentration ( $\mathrm{mg} \mathrm{kg}^{-1}$ )

Figure 4. Effect of $\mathrm{Si}$ on the fractions of $\mathrm{Cd}$ in soil for $(\mathbf{a}, \mathbf{c}, \mathbf{e}, \mathbf{g})$ P. glaucum $\times$ P. purpureum and $(\mathbf{b}, \mathbf{d}, \mathbf{f}, \mathbf{h})$ P. glaucum. (a,b) Exchangeable Cd. (c,d) Reducible Cd. (e,f) Oxidizable Cd. (g,h) Residual Cd. Values followed by the different letters indicate significant differences between the different treatments of the same variety, according to one-way ANOVA followed by the Duncan test $(p<0.05)$.

\section{Discussion}

\subsection{Si Mitigates Cd Toxicity and Improves Growth in Pennisetum}

Cd causes numerous changes in physiological and biochemical functions and structural destruction, thereby leading to significant restriction of growth and development in plants $[7,13,43]$. Our study showed that Cd treatment significantly inhibited the growth of Pennisetum, and the increased Cd level caused an evident decrease in biomass (Figure 1). This outcome is similar to the results on Pennisetum by Zhang et al. [44]. However, exogenous $\mathrm{Si}$ application has a significant effect in enhancing the toxic metal element tolerance of plants and reducing metal toxicity [23,24,44-47]. Song et al. [48] found that the growth of Cd-tolerant cultivar and Cd-sensitive cultivar of two pakchoi (Brassica chinensis L.) was severely inhibited under $\mathrm{Cd}$ stress, but $\mathrm{Si}$ application mitigated the toxic effects. In this study, Si significantly increases root and shoot biomass and improves plant growth, regardless of Cd levels for both Pennisetum (Figure 1), thereby indicating the significant role of $\mathrm{Si}$ in alleviating $\mathrm{Cd}$ toxicity.

\subsection{Si Impacts on Plant Cd Accumulation and Transportation}

Plants can readily absorb $\mathrm{Cd}$ upon exposure through the roots and translocate the metal element to the above-ground parts. Our studies showed that $\mathrm{Cd}$ concentration in roots, stems, and leaves of the two varieties increased with the rise of the $\mathrm{Cd}$ treated level (Table 1). This outcome is consistent with the study in which Cd plant uptake increased proportionally to increasing Cd concentration [49]. However, $\mathrm{Cd}$ concentration in shoots was lower than those in roots for P. glaucum $\times$ P. purpureum under the 50 and $100 \mathrm{mg} \cdot \mathrm{kg}^{-1} \mathrm{Cd}$ levels and P. glaucum under $100 \mathrm{mg} \cdot \mathrm{kg}^{-1} \mathrm{Cd}$. Therefore, Pennisetum, like many other plants, enriches toxic metal elements in roots [46,50].

The benefit of Si for plants under abiotic stress, including the reduced absorption and transportation of heavy metals by plants, is well known [51]. In our study, the Si concentration of roots and shoots in Si-treated plants was significantly higher (Table 2), and such upsurges were related to the increased plant resistance to $\mathrm{Cd}$ stress. Our study also found that $\mathrm{Si}$ application caused a significant decrease 
in Cd concentration in roots and shoots (Table 2) for both Pennisetum at the 50 and $100 \mathrm{mg} \cdot \mathrm{kg}^{-1} \mathrm{Cd}$ levels, while the $\mathrm{Cd}$ accumulation of plants did not change significantly (Table 2). Similar results were reported in other studies where $\mathrm{Si}$ addition significantly decreased $\mathrm{Cd}$ concentrations in both shoots and roots, regardless of $\mathrm{Cd}$ levels, but no significant effects on $\mathrm{Cd}$ accumulation were observed in shoots and roots [46,52]. As the amount of $\mathrm{Cd}$ accumulation is determined by both the Cd content and the biomass, Si-enhanced plant growth may induce the dilution effect, thereby leading to less toxicity [46,52]. Meanwhile, Cd concentration is reduced more in roots than in shoots with the addition of Si. This could be attributed to the reduction of $\mathrm{Cd}$ absorption. Furthermore, our study showed that Si application significantly reduced the EF values in roots and shoots of both Pennisetum (Table 2). Thus, plant $\mathrm{Cd}$ uptake was inhibited by $\mathrm{Si}$ and this is similar to the findings with wheat by Wu et al. [46]. The TF is used to evaluate the transferability of $\mathrm{Cd}$ from root to the shoot. In previous studies, Gao et al. [53] demonstrated that foliar spraying $\mathrm{Si}$ decreased $\mathrm{Cd}$ translocation from roots to stems and from stems to brown rice and increasing Cd translocation from stems to leaves in cultivars WYHZ. Shi et al. [54] found that $\mathrm{Si}$ deposition in the vicinity of endodermis could restrain the apoplastic transport of $\mathrm{Cd}$ and reduce the transport of $\mathrm{Cd}$ from roots to shoots. In our study, we found that $\mathrm{Si}$ had no consistent effects on TF for two varieties, reduced TF at $10 \mathrm{mg} \cdot \mathrm{kg}^{-1} \mathrm{Cd}$ level for P. glaucum, while having increased TF at 50 and $100 \mathrm{mg} \cdot \mathrm{kg}^{-1} \mathrm{Cd}$ level for P. glaucum $\times$ P. purpureum and P. glaucum, respectively, indicating variety difference of $\mathrm{Cd}$ translocation and other factors influencing the detoxification mechanism of $\mathrm{Si}$ on $\mathrm{Cd}$ toxicity. We speculated that $\mathrm{Si}$ reduces $\mathrm{Cd}$ toxicity mainly by reducing the uptake of $\mathrm{Cd}$ of Pennisetum rather than by reducing the transport of $\mathrm{Cd}$. This conclusion is similar to the study of $\mathrm{Wu}[46]$ on wheat.

\subsection{Silicon Influences $\mathrm{Cd}$ Bioavailability in Soil}

Heavy metals with different fractions in soil show large differences in migration ability, phytoextractability, and bioavailability [55]. Exchangeable Cd has strong migration ability and can be directly absorbed by plants [56]. Reducible and oxidizable $\mathrm{Cd}$ can be activated under specific conditions, whereas residual $\mathrm{Cd}$ is highly stable in soil and is not considered to be bioavailable for organisms $[57,58]$. Previous studies have shown that $\mathrm{Si}$ has important impacts on the metal bioavailability in soil [27]. In this study, $\mathrm{Si}$ addition reduced exchangeable/oxidizable/reducible (Figure $4 \mathrm{a}, \mathrm{e}, \mathrm{c}$, respectively) $\mathrm{Cd}$ in soil and increased residual Cd (Figure $4 \mathrm{~g}$ ) in P. glaucum $\times$ P. purpureum under the 50 and $100 \mathrm{mg} \cdot \mathrm{kg}^{-1} \mathrm{Cd}$ levels. Similarly, Si application resulted in the reduction of exchangeable Cd (Figure $4 \mathrm{~b}$ ) and the increase of residual Cd in soil (Figure 4h) in P. glaucum. Thus, $\mathrm{Si}$ addition caused the transformation of $\mathrm{Cd}$ fractions from availability into unavailability. Similar results were obtained in other investigations [23,26,59,60]. Liang et al. [23] reported that $400 \mathrm{mg} \cdot \mathrm{kg}^{-1} \mathrm{Si}$ application decreased water-and $\mathrm{CaCl}_{2}$ - extractable fractions of $\mathrm{Cd}$, but increased $\mathrm{Fe}-\mathrm{Mn}$ oxide-bound fractions, therefore more $\mathrm{Cd}$ was found in the form of specific adsorbed or Fe-Mn oxide-bound fractions in Si-amended soil. Cunha et al. [59] found that silicon altered Cd and Zn fractions in soil and mitigated the toxicity of $\mathrm{Cd}$ in maize, reduced most bioavailable fractions, and increased the allocation of metals into highly stable fractions.

Soil $\mathrm{pH}$ plays an important role in the fractions of heavy metals. Moreover, it can control the solubility of heavy metal ions [61] and thus promote the transformation of heavy metals from bioavailable to residual fractions and reduce the toxicity of heavy metals [62]. A negative correlation is generally believed to exist between soil $\mathrm{pH}$ and heavy metal mobility and availability in soil [63]. In our study, Si addition significantly increased soil $\mathrm{pH}$ (Figure 2), which is similar to other studies [23,64]. $\mathrm{Li}$ et al. [65] reported that the addition of $800 \mathrm{mg} \mathrm{Si} \mathrm{kg}^{-1}\left(\mathrm{Na}_{2} \mathrm{SiO}_{3}\right)$ to $\mathrm{Pb}$-contaminated soil significantly increased soil $\mathrm{pH}$, as well as the carbonate and residual bound fractions of $\mathrm{Pb}$, but reduced the exchangeable fraction of $\mathrm{Pb}$, consequently reducing plant availability of $\mathrm{Pb}$. Ding et al. [66] found that rhizosphere soil $\mathrm{pH}$ increased with the increase of $\mathrm{Si}$ level under different $\mathrm{Cr}$ levels. This trend indicated that exogenous $\mathrm{Si}$ induced the alkalization of rhizosphere soil, promoted the formation of precipitation-bound and organic matter-bound $\mathrm{Cr}$ in $\mathrm{Cr}$-contaminated soil, and probably improved 
the stability of $\mathrm{Cr}$ and decreased $\mathrm{Cr}$ uptake from $\mathrm{Cr}$-contaminated soil. Combined with the above evidence, our study indicated that Si-mediated detoxification of $\mathrm{Cd}$ is related to the increase of soil $\mathrm{pH}$ and residual $\mathrm{Cd}$ fraction but reduction of available $\mathrm{Cd}$ fractions, thereby reducing the absorption of $\mathrm{Cd}$ by Pennisetum.

\section{Conclusions}

In summary, our results suggest that $\mathrm{Si}$ can significantly influence the behavior of $\mathrm{Cd}$ in soil by altering its availability and reducing its uptake by plants. Si addition to $\mathrm{Cd}$-contaminated soil has an important role in in situ remediation by immobilizing $\mathrm{Cd}$ metal, thereby reducing $\mathrm{Cd}$ availability and improving plant growth. Additionally, the increases in soil $\mathrm{pH}$ and plant $\mathrm{Si}$ content resulting from $\mathrm{Si}$ application contribute to plant growth. Si impacts on P. glaucum $\times$ P. purpureum were more effective than those in P. glaucum in terms of reducing Cd uptake and increasing plant growth.

Author Contributions: K.C. conceived and designed the ideas and wrote the manuscript with the help of Q.D.; Q.D. conducted the experiments, collected and analyzed the data, and wrote the manuscript with the help of J.F. and F.H.; all authors contributed to the final version of this manuscript.

Funding: This study was financially supported by grants from the National Natural Science Foundation of China (31870420, 31370456) and the Natural Science Foundation of Guangdong Province of China (2017A030313177, S2012010010331)).

Conflicts of Interest: The authors declare that they have no competing financial interests. The funders had no role in the design of the study; in the collection, analyses, or interpretation of data; in the writing of the manuscript, or in the decision to publish the results.

\section{References}

1. Ali, S.; Farooq, M.A.; Yasmeen, T.; Hussain, S.; Arif, M.S.; Abbas, F.; Bharwana, S.A.; Zhang, G.P. The influence of silicon on barley growth, photosynthesis and ultra-structure under chromium stress. Ecotoxicol. Environ. Saf. 2013, 89, 66-72. [CrossRef] [PubMed]

2. Tudoreanu, L.; Phillips, C.J.C. Modeling cadmium uptake and accumulation in plants. Adv. Agron. 2004, 84, 121-157.

3. Salt, D.E.; Prince, R.C.; Pickering, I.J.; Raskin, I. Mechanisms of cadmium mobility and accumulation in Indian mustard. Plant Physiol. 1995, 109, 1427-1433. [CrossRef]

4. Takahashi, R.; Ishimaru, Y.; Shimo, H.; Ogo, Y.; Senoura, T.; Nishizawa, N.K.; Nakanishi, H. The OsHMA2 transporter is involved in root-to-shoot translocation of $\mathrm{Zn}$ and $\mathrm{Cd}$ in rice. Plant Cell Environ. 2012, 35, 1948-1957. [CrossRef]

5. Nakanishi, H.; Ogawa, I.; Ishimaru, Y.; Mori, S.; Nishizawa, N.K. Iron deficiency enhances cadmium uptake and translocation mediated by the $\mathrm{Fe}^{2+}$ transporters OsIRT1 and OsIRT2 in rice. Soil Sci. Plant Nutr. 2006, 52, 464-469. [CrossRef]

6. $\quad$ Feng, J.P.; Shi, Q.H.; Wang, X.F.; Wei, M.; Yang, F.J.; Xu, H.N. Silicon supplementation ameliorated the inhibition of photosynthesis and nitrate metabolism by cadmium (Cd) toxicity in Cucumis sativus L. Sci. Hortic. 2010, 123, 521-530. [CrossRef]

7. Ali, B.; Qian, P.; Jin, R.; Ali, S.; Khan, M.; Aziz, R.; Tian, T.; Zhou, W. Physiological and ultra-structural changes in Brassica napus seedlings induced by cadmium stress. Biol. Plant. 2014, 58, 131-138. [CrossRef]

8. Nomiyama, K. Recent progress and perspectives in cadmium health effects studies. Sci. Total Environ. 1980, 14, 199-232. [CrossRef]

9. Kirkham, M.B. Cadmium in plants on polluted soils: Effects of soil factors, hyperaccumulation, and amendments. Geoderma 2006, 1-2, 19-32. [CrossRef]

10. Fu, S.; Wei, C.Y. Multivariate and spatial analysis of heavy metal sources and variations in a large old antimony mine, China. J. Soils Sediments 2013, 13, 106-116. [CrossRef]

11. Li, W.L.; Xu, B.B.; Song, Q.J.; Liu, X.M.; Xu, J.M.; Brookes, P.C. The identification of 'hotspots' of heavy metal pollution in soil-rice systems at a regional scale in eastern China. Sci. Total Environ. 2014, 472, 407-420. [CrossRef] 
12. Shi, Y.; Zhang, Y.; Yao, H.; Wu, J.W.; Sun, H.; Gong, H.J. Silicon improves seed germination and alleviates oxidative stress of bud seedlings in tomato under water deficit stress. Plant Physiol. Biochem. 2014, 78, 27-36. [CrossRef]

13. Wu, Z.C.; Wang, F.H.; Liu, S.; Du, Y.Q.; Li, F.R.; Du, R.Y.; Wen, D.; Zhao, J. Comparative responses to silicon and selenium in relation to cadmium uptake, compartmentation in roots, and xylem transport in flowering Chinese cabbage (Brassica campestris L. ssp. chinensis var. utilis) under cadmium stress. Environ. Exp. Bot. 2016, 131, 173-180. [CrossRef]

14. Liang, Y.C.; Song, A. Silicon uptake and transport in plants: Physiological and molecular aspects. In Silicon in Agriculture: From Theory to Practice; Nikolic, M., Belanger, R., Gong, H.J., Song, A., Eds.; Springer: Dordrecht, The Netherlands, 2015; pp. 69-79.

15. Guntzer, F.; Keller, C.; Meunier, J. Benefits of plant silicon for crops: A review. Agron. Sustain. Dev. 2012, 32, 201-213. [CrossRef]

16. Meharg, C.; Meharg, A.A. Silicon, the silver bullet for mitigating biotic and abiotic stress, and improving grain quality, in rice? Environ. Exp. Bot. 2015, 120, 8-17. [CrossRef]

17. Naeem, A.; Zia-ur-Rehman, M.; Akhtar, T.; Hussain, M.Z.; Aslam, M. Silicon nutrition lowers cadmium content of wheat cultivars by regulating transpiration rate and activity of antioxidant enzymes. Environ. Pollut. 2018, 242, 126-135. [CrossRef]

18. Anwaar, S.A.; Ali, S.; Ali, S.; Ishaque, W.; Farid, M.; Farooq, M.A.; Najeeb, U.; Abbas, F.; Sharif, M. Silicon (Si) alleviates cotton (Gossypium hirsutum L.) from zinc $(\mathrm{Zn})$ toxicity stress by limiting $\mathrm{Zn}$ uptake and oxidative damage. Environ. Sci. Pollut. Res. 2015, 22, 3441-3450. [CrossRef]

19. Che, J.; Yamaji, N.; Shao, J.F.; Ma, J.F.; Shen, R.F. Silicon decreases both uptake and root-to-shoot translocation of manganese in rice. J. Exp. Bot. 2016, 67, 1535-1544. [CrossRef]

20. Freitas, L.B.D.; Fernandes, D.M.; Maia, S.C.M.; Fernandes, A.M. Effects of silicon on aluminum toxicity in upland rice plants. Plant Soil 2017, 420, 263-275. [CrossRef]

21. Liu, J.; Cai, H.; Mei, C.; Wang, M. Effects of nano-silicon and common silicon on lead uptake and translocation in two rice cultivars. Front. Environ. Sci. Eng. 2015, 9, 905-911. [CrossRef]

22. Keller, C.; Rizwan, M.; Davidian, J.C.; Pokrovsky, O.S.; Bovet, N.; Chaurand, P.; Meunier, J.D. Effect of silicon on wheat seedlings (Triticum turgidum L.) grown in hydroponics and exposed to 0 to $30 \mu \mathrm{M} \mathrm{Cu}$. Planta 2015, 241, 847-860. [CrossRef] [PubMed]

23. Liang, Y.C.; Wong, J.; Wei, L. Silicon-mediated enhancement of cadmium tolerance in maize (Zea mays L.) grown in cadmium contaminated soil. Chemosphere 2005, 58, 475-483. [CrossRef] [PubMed]

24. Liang, Y.C.; Sun, W.C.; Zhu, Y.G.; Christie, P. Mechanisms of silicon-mediated alleviation of abiotic stresses in higher plants: A review. Environ. Pollut. 2007, 147, 422-428. [CrossRef]

25. Zhang, C.; Wang, L.; Nie, Q.; Zhang, W.X.; Zhang, F.S. Long-term effects of exogenous silicon on cadmium translocation and toxicity in rice (Oryza sativa L.). Environ. Exp. Bot. 2008, 62, 300-307. [CrossRef]

26. Wu, J.W.; Shi, Y.; Zhu, Y.X.; Wang, Y.C.; Gong, H.J. Mechanisms of Enhanced Heavy Metal Tolerance in Plants by Silicon: A Review. Pedosphere 2013, 23, 815-825. [CrossRef]

27. Liang, Y.C.; Song, A. Silicon-mediated tolerance to metal toxicity. In Silicon in Agriculture: From Theory to Practice; Nikolic, M., Belanger, R., Gong, H.J., Song, A., Eds.; Springer: Dordrecht, The Netherlands, 2015; pp. 95-99.

28. Rizwan, M.; Ali, S.; Adrees, M.; Rizvi, H.; Zia-ur-Rehman, M.; Hannan, F.; Qayyum, M.F.; Hafeez, F.; Ok, Y.S. Cadmium stress in rice: Toxic effects, tolerance mechanisms, and management: A critical review. Environ. Sci. Pollut. Res. 2016, 23, 17859-17879. [CrossRef] [PubMed]

29. Farooq, M.A.; Ali, S.; Hameed, A.; Ishaque, W.; Mahmood, K.; Iqbal, Z. Alleviation of cadmium toxicity by silicon is related to elevated photosynthesis, antioxidant enzymes; suppressed cadmium uptake and oxidative stress in cotton. Ecotoxicol. Environ. Saf. 2013, 96, 242-249. [CrossRef]

30. Howladar, S.M.; Al-Robai, S.A.; Al-Zahrani, F.S.; Howladar, M.M.; Aldhebiani, A.Y. Silicon and its application method effects on modulation of cadmium stress responses in Triticum aestivum (L.) through improving the antioxidative defense system and polyamine gene expression. Ecotoxicol. Environ. Saf. 2018, 159, 143-152. [CrossRef]

31. Vaculik, M.; Landberg, T.; Greger, M.; Luxová, M.; Stoláriková, M.; Lux, A. Silicon modifies root anatomy, and uptake and subcellular distribution of cadmium in young maize plant. Ann. Bot. 2012, 110, 433-443. [CrossRef] 
32. Ma, J.F.; Cai, H.M.; He, C.W.; Zhang, W.J.; Wang, L.J. A hemicellulose-bound form of silicon inhibits cadmium ion uptake in rice (Oryza sativa) cells. New Phytol. 2015, 206, 1063-1074. [CrossRef]

33. Liu, J.; Ma, J.; He, C.W.; Li, X.L.; Zhang, W.J.; Xu, F.X.; Lin, Y.J.; Wang, L.J. Inhibition of cadmium ion uptake in rice (Oryza sativa) cells by a wall-bound form of silicon. New Phytol. 2013, 200, 691-699. [CrossRef]

34. Greger, M.; Kabir, A.H.; Landberg, T.; Maity, P.J.; Maity, L. Silicate reduces cadmium uptake into cells of wheat. Environ. Pollut. 2016, 211, 90-97. [CrossRef]

35. Shao, J.F.; Che, J.; Yamaji, N.; Shen, R.F.; Ma, J.F. Silicon reduces cadmium accumulation by suppressing expression of transporter genes involved in cadmium uptake and translocation in rice. J. Exp. Bot. 2017, 68, 5641-5651. [CrossRef]

36. Singh, D.; Raghuvanshi, K.; Chaurasiya, A.; Dutta, S.K.; Dubey, S.K. Enhancing the nutrient uptake and quality of pearlmillet (Pennisetum glaucum L.) through use of biofertilizers. Int. J. Curr. Microbiol. Appl. Sci. 2018, 7, 3296-3306. [CrossRef]

37. Yousaf, A.; Athar, M.; Salman, M.; Farooq, U.; Chawla, F.S. Biosorption characteristics of Pennisetum glaucum for the removal of $\mathrm{Pb}(\mathrm{II}), \mathrm{Ni}(\mathrm{II})$ and $\mathrm{Cd}(\mathrm{II})$ ions from aqueous medium. Green Chem. Lett. Rev. 2017, 10, 462-470. [CrossRef]

38. Elliott, C.L.; Snyder, G.H. Autoclave-induced digestion for the colorimetric determination of silicon in rice straw. J. Agric. Food Chem. 1991, 39, 1118-1119. [CrossRef]

39. Bian, R.; Li, L.; Bao, D.; Zheng, J.; Zhang, X.; Zheng, J.; Liu, X.; Cheng, K.; Pan, G. Cd immobilization in a contaminated rice paddy by inorganic stabilizers of calcium hydroxide and silicon slag and by organic stabilizer of biochar. Environ. Sci. Pollut. Res. 2016, 23, 10028-10036. [CrossRef] [PubMed]

40. Zhang, Q.; Yan, C.L.; Liu, J.C.; Lu, H.L.; Duan, H.H.; Du, J.N.; Wang, W.Y. Silicon alleviation of cadmium toxicity in mangrove (Avicennia marina) in relation to cadmium compartmentation. J. Plant Growth Regul. 2014, 33, 233-242. [CrossRef]

41. Fuentes, A.; Lloréns, M.; Sáez, J.; Isabel-Aguilar, M.; Ortuo, J.F.; Meseguer, V.F. Comparative study of six different sludges by sequential speciation of heavy metals. Bioresour. Technolgy 2008, 99, 517-525. [CrossRef]

42. Rauret, G.; Rubio, R.; López-Sánchez, J.F. Optimization of Tessier procedure for metal solid speciation in river sediments. Int. J. Environ. Anal. Chem. 1989, 36, 69-83. [CrossRef]

43. Lux, A.; Martinka, M.; Vaculík, M.; White, P.J. Root responses to cadmium in the rhizosphere: A review. J. Exp. Bot. 2010, 62, 21-37. [CrossRef]

44. Zhang, X.F.; Zhang, X.H.; Gao, B.; Li, Z.; Xia, H.P.; Li, H.F.; Li, J. Effect of cadmium on growth, photosynthesis, mineral nutrition and metal accumulation of an energy crop, king grass (Pennisetum americanum $\times$ P. purpureum). Biomass Bioenergy 2014, 67, 179-187. [CrossRef]

45. Lu, H.P.; Li, Z.; Wu, J.T.; Shen, Y.; Li, Y.W.; Zou, B.; Tang, Y.T.; Zhuang, P. Influences of calcium silicate on chemical forms and subcellular distribution of cadmium in Amaranthus hypochondriacus L. Sci. Rep. 2017, 7, 40583. [CrossRef]

46. Wu, J.; Geilfus, C.; Pitann, B.; Mühling, K.H. Silicon-enhanced oxalate exudation contributes to alleviation of cadmium toxicity in wheat. Environ. Exp. Bot. 2016, 131, 10-18. [CrossRef]

47. Vaculck, M.; Lux, A.; Luxovcl, M.; Tanimoto, E.; Lichtscheidl, I. Silicon mitigates cadmium inhibitory effects in young maize plants. Environ. Exp. Bot. 2009, 67, 52-58. [CrossRef]

48. Song, A.; Li, Z.; Zhang, J.; Xue, G.; Fan, F.; Liang, Y. Silicon-enhanced resistance to cadmium toxicity in Brassica chinensis L. is attributed to Si-suppressed cadmium uptake and transport and Si-enhanced antioxidant defense capacity. J. Hazard. Mater. 2009, 172, 74-83. [CrossRef]

49. Rizwan, M.; Meunier, J.D.; Davidian, J.C.; Pokrovsky, O.S.; Bovet, N.; Keller, C. Silicon alleviates Cd stress of wheat seedlings (Triticum turgidum L. cv. Claudio) grown in hydroponics. Environ. Sci. Pollut. Res. 2016, 23, 1414-1427. [CrossRef]

50. Alexander, P.D.; Alloway, B.J.; Dourado, A.M. Genotypic variations in the accumulation of $\mathrm{Cd}, \mathrm{Cu}, \mathrm{Pb}$ and Zn exhibited by six commonly grown vegetables. Environ. Pollut. 2006, 144, 736-745. [CrossRef]

51. Naeem, A.; Saifullah; Ghafoor, A.; Farooq, M. Suppression of cadmium concentration in wheat grains by silicon is related to its application rate and cadmium accumulating abilities of cultivars. J. Sci. Food Agric. 2015, 95, 2467-2472. [CrossRef]

52. Rizwan, M.; Meunier, J.; Miche, H.; Keller, C. Effect of silicon on reducing cadmium toxicity in durum wheat (Triticum turgidum L. cv. Claudio W.) grown in a soil with aged contamination. J. Hazard. Mater. 2012, 209-210, 326-334. [CrossRef] 
53. Gao, M.; Zhou, J.; Liu, H.; Zhang, W.; Hu, Y.; Liang, J.; Zhou, J. Foliar spraying with silicon and selenium reduces cadmium uptake and mitigates cadmium toxicity in rice. Sci. Total Environ. 2018, 631, 1100-1108. [CrossRef]

54. Shi, X.; Zhang, C.; Wang, H.; Zhang, F. Effect of Si on the distribution of Cd in rice seedlings. Plant Soil 2005, 272, 53-60. [CrossRef]

55. Khan, S.; Chao, C.; Waqas, M.; Arp, H.P.H.; Zhu, Y.G. Sewage sludge biochar influence upon rice (Oryza sativa L.) yield, metal bioaccumulation and greenhouse gas emissions from acidic paddy soil. Environ. Sci. Technol. 2013, 47, 8624-8632. [CrossRef]

56. Sungur, A.; Soylak, M.; Yilmaz, S.; Özcan, H. Determination of heavy metals in sediments of the Ergene River by BCR sequential extraction method. Environ. Earth Sci. 2014, 72, 3293-3305. [CrossRef]

57. Memoli, V.; Eymar, E.; García-Delgado, C.; Esposito, F.; Santorufo, L.; Marco, A.D.; Barile, R.; Maisto, G. Total and fraction content of elements in volcanic soil: Natural or anthropogenic derivation. Sci. Total Environ. 2018, 625, 16-26. [CrossRef]

58. Fuentes, A.; Lloréns, M.; Sáez, J.; Aguilar, M.I.; Fortuño, J.; Meseguer, V.F. Phytotoxicity and heavy metals speciation of stabilised sewage sludges. J. Hazard. Mater. 2004, 108, 161-169. [CrossRef]

59. Cunha, K.P.V.D.; Silva, A.J.D. Silicon alleviates the toxicity of cadmium and zinc for maize (Zea mays L.) grown on a contaminated soil. J. Plant Nutr. Soil Sci. 2010, 171, 849-853. [CrossRef]

60. Gu, H.H.; Qiu, H.; Tian, T.; Zhan, S.S.; Deng, T.H.B.; Chaney, R.L.; Wang, S.Z.; Tang, Y.T.; Morel, J.L.; Qiu, R.L. Mitigation effects of silicon rich amendments on heavy metal accumulation in rice (Oryza sativa L.) planted on multi-metal contaminated acidic soil. Chemosphere 2011, 83, 1234-1240. [CrossRef]

61. Schmidt, U. Enhancing phytoextraction: The effect of chemical soil manipulation on mobility, plant accumulation, and leaching of heavy metals. J. Environ. Qual. 2003, 32, 1939-1954. [CrossRef]

62. Adrees, M.; Ali, S.; Rizwan, M.; Zia-ur-Rehman, M.; Ibrahim, M.; Abbas, F.; Farid, M.; Qayyum, M.F.; Irshad, M.K. Mechanisms of silicon-mediated alleviation of heavy metal toxicity in plants: A review. Ecotoxicol. Environ. Saf. 2015, 119, 186-197. [CrossRef]

63. Zeng, F.R.; Ali, S.; Zhang, H.T.; Ouyang, Y.N.; Qiu, B.Y.; Wu, F.B. The influence of pH and organic matter content in paddy soil on heavy metal availability and their uptake by rice plants. Environ. Pollut. 2011, 159, 84-91. [CrossRef] [PubMed]

64. Lu, H.P.; Zhuang, P.; Li, Z.A.; Tai, Y.P.; Zou, B.; Li, Y.W.; Mcbride, M.B. Contrasting effects of silicates on cadmium uptake by three dicotyledonous crops grown in contaminated soil. Environ. Sci. Pollut. Res. 2014, 21, 9921-9930. [CrossRef]

65. Li, L.B.; Zheng, C.; Fu, Y.Q.; Wu, D.M.; Yang, X.J.; Shen, H. Silicate-Mediated Alleviation of Pb Toxicity in Banana Grown in Pb-Contaminated Soil. Biol. Trace Elem. Res. 2012, 145, 101-108. [CrossRef] [PubMed]

66. Ding, X.D.; Zhang, S.R.; Li, S.Y.; Li, F.B.; Liu, C.P.; Liao, X.R.; Wang, R.P. Silicon mediated the detoxification of Cr on pakchoi (Brassica chinensis L.) in Cr-contaminated soil. Procedia Environ. Sci. 2013, 18, 58-67. [CrossRef] 